This article was downloaded by: [Universiteit Antwerpen]

On: 15 November 2013, At: 06:21

Publisher: Routledge

Informa Ltd Registered in England and Wales Registered Number: 1072954

Registered office: Mortimer House, 37-41 Mortimer Street, London W1T 3J H, UK

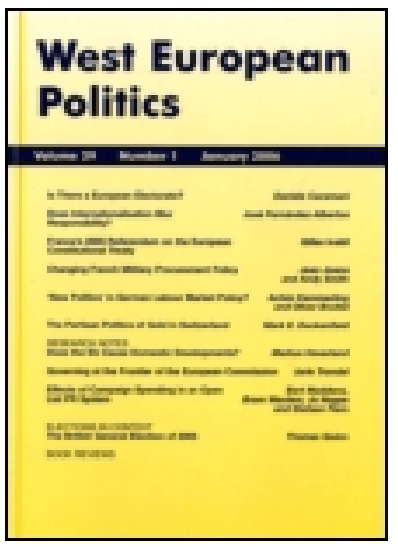

West European Politics

Publication details, including instructions for authors and subscription information:

http:/ / www.tandfonline.com/ loi/ fwep20

\title{
Constructing a Policy-Making State? Policy Dynamics in the EU
}

\author{
Iskander De Bruycker ${ }^{\text {a }}$ \\ a University of Antwerp \\ Published online: 06 Aug 2013.
}

To cite this article: Iskander De Bruycker (2013) Constructing a Policy-Making State? Policy Dynamics in the EU, West European Politics, 36:5, 1116-1117, DOI: 10.1080/01402382.2013.820429

To link to this article: http:// dx. doi.org/ 10.1080/01402382.2013.820429

\section{PLEASE SCROLL DOWN FOR ARTICLE}

Taylor \& Francis makes every effort to ensure the accuracy of all the information (the "Content") contained in the publications on our platform. However, Taylor \& Francis, our agents, and our licensors make no representations or warranties whatsoever as to the accuracy, completeness, or suitability for any purpose of the Content. Any opinions and views expressed in this publication are the opinions and views of the authors, and are not the views of or endorsed by Taylor \& Francis. The accuracy of the Content should not be relied upon and should be independently verified with primary sources of information. Taylor and Francis shall not be liable for any losses, actions, claims, proceedings, demands, costs, expenses, damages, and other liabilities whatsoever or howsoever caused arising directly or indirectly in connection with, in relation to or arising out of the use of the Content.

This article may be used for research, teaching, and private study purposes. Any substantial or systematic reproduction, redistribution, reselling, loan, sublicensing, systematic supply, or distribution in any form to anyone is expressly 
forbidden. Terms \& Conditions of access and use can be found at http:// www.tandfonline.com/page/terms-and-conditions 
interpretation of this key principle in opinions submitted by national parliaments to several drafts under the Barroso Initiative (the precursor of the EWS organised by COSAC, the Conference of European Affairs Committees), Kiiver proposes a bottomup, lowest-common-denominator-type definition of subsidiarity, which would make sure that at least some coherence is achieved among different parliaments in usage of the term.

Against most observers' scepticism about the added value of the EWS in terms of democracy and legitimacy, Kiiver is cautiously optimistic about the prospects of the new mechanisms. The main argument of the book is that the EWS can indeed become a catalyst for more parliamentary involvement if it manages to raise awareness among MPs in national parliaments. As the case of the Monti II regulation shows, which has reached for the first time a 'yellow card' less than one month after The Early Warning System for the Principle of Subsidiarity has left the printing press, this optimism was well-founded. In order to make the EWS work, realistic expectations about the scope, purpose and potential effects of the new mechanism are of crucial relevance. Kiiver argues against the narrow focus on the (still quite weak) veto powers national parliaments might use to block EU legislation and makes the case for re-conceptionalising the EWS as an accountability mechanism. Thus, the main added value of the EWS is not to veto Brussels, but to make it justify and explain new legislation. Rather than acting as policy-makers in an overly complex multi-level system, what national parliaments are particularly good at is demanding accountability, transparency and dialogue across levels of governments. Kiiver shows that, so far, parliaments engage mostly in checking legal accountability. However, to avoid frustration, parliaments would do better concentrating on their role as a forum for democratic accountability. At the same time, making the EWS work will still be stifled by the extensive differences in how national parliaments - typologised by the author as 'literalists', 'pseudo-colegislators', 'pre-empters' and 'absentees' - self-assess their role in performing EU scrutiny.

The book closes with several ideas on how the EWS can be strengthened in practice and proposes research questions for the academic communities. We can only hope that both practical and academic ideas will be taken up by practitioners in national parliaments and legislative scholars working on questions of democracy and multi-level parliamentarianism. If so, due to its interdisciplinary strengths and its early conception, 'The Early Warning System for the Principle of Subsidiarity' promises to become a first step towards an empirically saturated research agenda on national parliaments in the European Union - and maybe also one that helped the EWS to unfold its strengths.

Aron Buzogány

German Public Administration Research Institute, Speyer http://dx.doi.org/10.1080/01402382.2013.820428

\section{Constructing a Policy-Making State? Policy Dynamics in the EU}

Edited by Jeremy Richardson

Oxford University Press, Oxford, 2012, 448 pp., £59.00, ISBN 978-0-19-960410-4 (hbk)

This edited volume explores the sources and boundaries of European integration. Jeremy Richardson, the editor, heads off by situating different theories and literature streams in EU policy studies and reflects on the European Union as a policy-making system and state. He introduces the different contributions, which have an in-depth focus either on one specific policy field (such as steel, health, energy, competition) or on one of the different policy-making stadia (agenda setting, implementation).

The detailed focus on a broad diversity of policy fields is one of the great strengths of this book. It gives the reader the opportunity to compare these fields with one 
another. Every contribution deals with how European integration takes place and which factors facilitate or impede this process. The different approaches across the chapters illustrate the tension between the neo-functionalist and intergovernmental perspective on European integration. The majority of contributions focus on the European Commission and the European Court of Justice as the driving forces of European integration. For example, Sonia Mazey argues that, for the case of EU women's rights, European integration was strongly driven by interactions between the Commission and EU women activists. Other authors argue that the locus of power and the motor of European integration has remained with the member states. Andreas Dür, for example, argues that in the EU's foreign economic policies, European integration has been mainly driven by the member states, which maintain control over the European Commission. Gerda Falkner, on the other hand, aims to overcome the tension between the neo-functionalist and intergovernmentalist approach in her contribution. Yet do these theoretical approaches need to be integrated or are they entwined with the policy field under scrutiny? When looking at the diversity of policy fields addressed in the book, a reader may draw the conclusion that the motor of European integration strongly varies from policy field to policy field. In this sense, an intergovernmental or neo-functionalist approach is more appropriate, depending on the policy field under the looking glass.

A less prominent, but nevertheless interesting theme in some of the chapters is how policy-making is understood. Sebastiaan Princen, for example, argues that how policy is framed has important consequences on whether or not an issue reaches the EU legislative agenda. Christoph Knill and Jale Tosun maintain that learning processes and information exchange are key ingredients in the implementation process of EU policy. This attention to framing, social interaction and learning processes seems to be a growing trend in EU policy studies. Does this trend announce the rise of constructivism in an institutionalist tradition?

Notwithstanding its strengths, the approach this book takes by thoroughly scrutinising different policy fields comes at a cost. The reader can easily get lost in technicalities and legal details, getting distracted from the core argument that each author wants to make. A second downside is that, despite a brief note in the final chapter, the volume remains strikingly silent about the role of the European Parliament, political parties and electoral politics in European public policymaking.

This book should be recommended reading for students of EU policy-making. Those who are looking for in-depth knowledge on one case may find what they seek in the chapters addressing a particular policy field. For those who have a broader interest and seek encompassing knowledge on EU policy-making, the chapters of the editor and that of Sebastiaan Princen are highly recommended.

$$
\begin{array}{r}
\text { Iskander De Bruycker } \\
\text { University of Antwerp }
\end{array}
$$

\section{Constitutionalism and the Enlargement of Europe By Wojciech Sadurski \\ Oxford University Press, Oxford, 2012, 262 pp., £60.00, ISBN 978-0-19-969678-9 (hbk)}

The impact of Eastern enlargement on the Council of Europe (CoE) and the European Union (EU) is the topic of this latest book by Wojciech Sadurski. This book gives special attention to 'constitutionalism' - an approach to governance that enshrines a text interpreted by a Constitutional Court (de facto or de jure) as controlling all other acts of state. 'Constitutions' usually invoke nation-states peopled by citizens sharing a common identity and allegiance. This book is particularly interesting because it analyses 